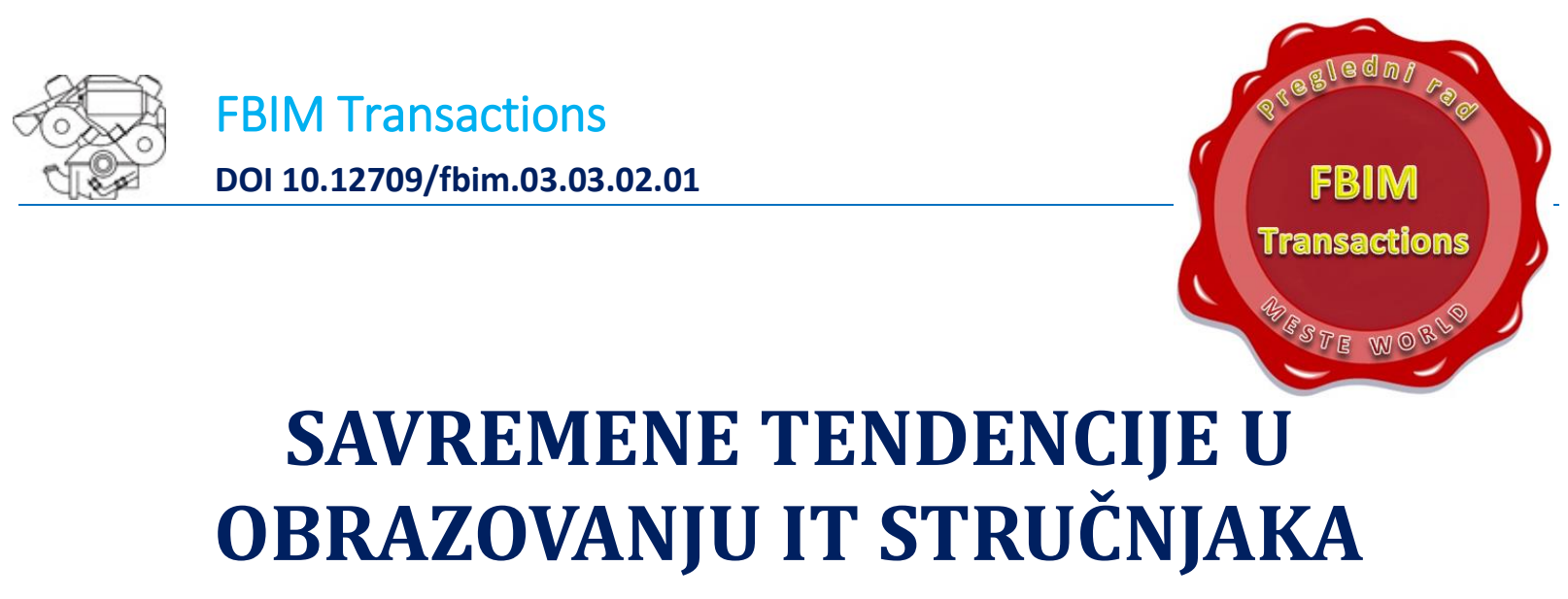

\title{
CONTEMPORARY TRENDS IN EDUCATION OF IT PROFESSIONALS
}

\section{Svetlana Anđelić}

Visoka škola strukovnih studija za informacione tehnologije - ITS, Beograd

- Zemun, Srbija

\section{Valentin Kuleto}

Visoka škola strukovnih studija za informacione tehnologije - ITS, Beograd

- Zemun, Srbija

(c) MESTE NGO

JEL category: E24, 121, L86

\section{Apstrakt}

Problem kontinuiranog rasta stope nezaposlenosti je evidentan u celom svetu, kako u zemljama u tranziciji, tako i u tehnološki razvijenim državama. Jedno od osnovnih pitanja koje se nameće je, svakako, i sagledavanje obrazovnog profila nezaposlenih osoba, odnosno stručnih kompetencija evidentiranih lica na tržištu rada. Velikoj nezaposlenosti, sigurno, je doprinela i hiperprodukcija određenog profila radnika, kao i neadekvatno obrazovanje tj. znanje koje oni poseduju nakon sticanja diploma. Kako bi se navedeni problem prevazišao u narednom periodu neophodno je analizirati potražnju, odnosno odrediti koji kadrovi su najtraženiji, pa čak i deficitarni na tržištu. Cilj je da se školuju stručnjaci koji će biti konkurentni nakon završetka studija, pa se shodno tome moraju prilagoditi nastavni planovi i programi. Ovde se ima na umu i formalni i neformalni vid obrazovanja. S obzirom da su se računari "uvukli" u sve sfere savremenog društva razumljivo je zašto su stručnjaci iz IT oblasti na prvom mestu. Treba napomenuti da prema zvaničnim podacima Republičkog zavoda za statistiku Republike Srbije čak $100 \%$ firmi koristi računare u svom poslovanju. Visoka škola strukovnih studija za informacione tehnologije u Beogradu (ITS) je sprovela istraživanje potražnje za IT kadrovima u Srbiji tokom 2013. godine. Razmatrani su svi oglasi koji su objavljeni za kategoriju IT na portalima www.poslovi.rs i www.poslovi.infostud.com, počevši od 01.01.2013. do 31.12.2013. godine. Ovi portali su uzeti kao referentni iz razloga što je na njima najveća ponuda poslovnih oglasa kod nas. U navedenom periodu objavljeno je preko 1500 oglasa

Adresa autora zaduženog za korespodenciju:

Svetlana Anđelić

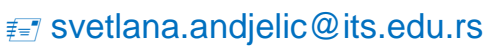

za navedenu kategoriju. $U$ radu su izloženi najznačajniji rezultati $i$ zaključci tog istraživanja uz kratke komentare. 
Ključne reči: IT stručnjaci, veb programeri, programeri mobilnih aplikacija, problemski orijentisana nastava, interaktivna nastava

\section{Abstract}

The problem of continuous growth in the unemployment rate is evident throughout the world, in the countries in transition as well as in the technologically advanced countries. One of the fundamental questions is, of course, the consideration of the educational profile of the unemployed or professional competence of registered persons in the labor market. The overproduction of certain workers' skills and inadequate education i.e. knowledge workers possess upon graduation has certainly contributed to the high unemployment rates. In order to overcome this problem in the future it is necessary to analyze the demand and determine which positions are the most sought after, and in short supply in the market. The goal is to educate professionals who will be competitive in the market after graduation and the curricula must be adapted accordingly. Here we have in mind formal as well as informal type of education. Since computers are present in all spheres of modern society, it is understandable why experts in the IT field are top rated. It should be noted that according to the official data of the Statistical Office of the Republic of Serbia as much as $100 \%$ of companies use computers in their business. Information Technology School in Belgrade (ITS) conducted a survey of demand for IT staff in Serbia during the year 2013. All ads that are published for the IT category on portals www.poslovi.rs and www.poslovi.infostud.com starting from 1st January 2013 to 31st December 2013 are taken into consideration. These portals are taken as a reference because they offer the largest number of employment ads in our country. During this period, they published more than 1500 listings for the specified category. This paper will present the most important results and conclusions of this study with brief comments.

Keywords: IT professionals, web developers, developers of mobile applications, problem-oriented teaching, interactive teaching

\section{UVOD}

Prema zvaničnim podacima Republičkog zavoda za statistiku Republike Srbije u oktobru 2013. godine u Srbiji je stopa nezaposlenosti iznosila oko $21 \%$ među licima radnog uzrasta (od 15 do 64 godine) (Aktuelni pokazatelji - Anketa o radnoj snazi, 2013). U 2014-oj je iznosila 22,2\%, a 2015. bi trebalo da padne na $21,5 \%$ (MOR, 2015)
U Mesečnom statističkom biltenu za februar 2014. godine Nacionalne službe za zapošljavanje, Republike Srbije se navodi da je oko $13,5 \%$ nezaposlenih sa VI, odnosno VII stepenom stručne spreme (Slika 1) (Mesečni statistički bilten za februar 2014. godine, 2014).

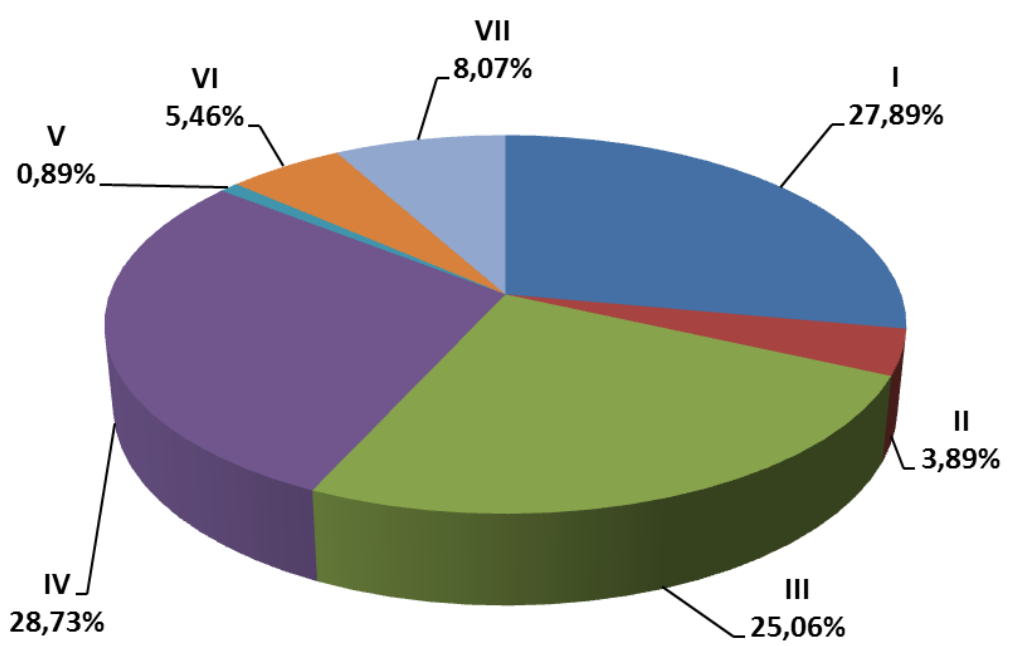

Slika 1. Struktura nezaposlenih lica u februaru 2014. prema stepenu stručne spreme (Mesečni statistički bilten za februar 2014. godine, 2014) 
Logično pitanje koje se nameće je zašto je ovako veliki procenat nezaposlenih kod visokoobrazovanih lica. Odnosno, da li je u pitanju hiperprodukcija određenih zanimanja ili neadekvatna kvalifikacija i stručna kompetencija tih lica?

U svakom slučaju uviđa se potreba dugoročnog predviđanja profila za kojima će biti potražnja i u narednom periodu. Shodno ovim podacima bi trebalo uskladiti upisne kvote na visokoobrazovnim institucijama i obezbediti adekvatno obrazovanje mladih.

S obzirom da su se računari "uvukli" u sve sfere savremenog društva razumljivo je zašto su stručnjaci iz IT oblasti najtraženiji. Primera radi prema podacima za 2013. godinu 59,9\% domaćinstava u Srbiji poseduju računar, a 55,8\% poseduje Internet priključak. Prema istom izvoru $100 \%$ preduzeća u Srbiji koriste računar u svom poslovanju, 99,6\% njih koristi Internet u svom poslovanju, a 73,8\% ima svoj veb sajt (Upotreba informaciono-komunikacionih tehnologija u Republici Srbiji, 2013).

lako je trenutni trend za IT stručnjacima veliki, ovo nikako ne treba da uljuljka visokoobrazovne institucije koje školuju pomenute kadrove i da pomisle kako ništa ne treba da menjaju u svojim nastavnim planovima i programima. Šta više, s obzirom da je ovo oblast (misli se na IT) koja se permanentno unapređuje i menja, shodno tome se moraju brzo i adekvatno adaptirati nastavni predmeti tj. studijski programi koji se odnose na IT struku.

Kako bi školova konkurentne kadrove na tržištu rada Visoka škola strukovnih studija za informacione tehnologije u Beogradu (ITS) redovno sprovodi istraživanje potražnje za IT kadrovima u Srbiji, odnosno kompetencije koje poslodavac zahteva od svojih zaposlenih. U ovom radu će biti izneti najznačajniji podaci za 2013. godinu.

\section{NAJTRAŽENIJE IT VEŠTINE U SRBIJI U 2013. GODINI}

Istraživanje koje je sproveo ITS obuhvata pregled svih oglasa iz kategorije IT sa sajtova www.poslovi.rs i poslovi.infostud.com tokom 2013. godine. Ovi portali su uzeti kao referentni iz razloga što je na njima najveća ponuda poslovnih oglasa kod nas. Oglasi su razmatrani u jednakim intervalima od 7 dana.

Radi lakše analize, IT oblast je podeljena na šest manjih segmenata: programski jezici, skript jezici, „software frameworks" tj. platforme za razvoj aplikacija (skraćeno, tehnologije), baze podataka (skraćeno baze), operativne sisteme (OS) i multimedijalni alati i tehnologije (skraćeno, multimedija).

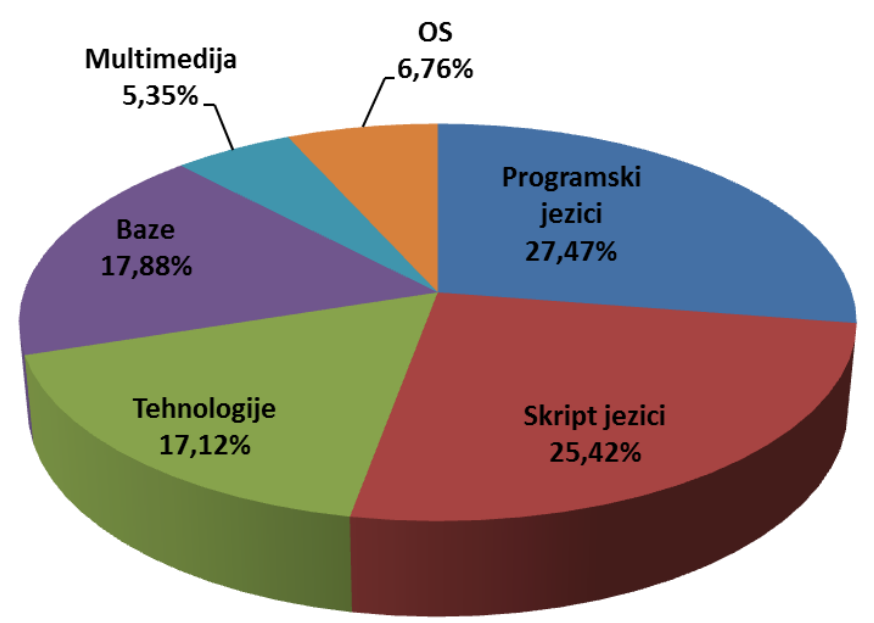

Slika 2. Procentualna potražnja po segmentima u IT oblasti

$\mathrm{Na}$ slici 2 je prikazana procentualna potražnja za određenim segmentima. Primećuje se da se u preko $50 \%$ slučajeva traži poznavanje programskih i „script“ jezika (Slika 2). Ako se tome doda i tražnja za odgovarajućim tehnologijama zaključuje se da se čak $70 \%$ stavki odnosilo na određene programerske veštine i znanja. Odnosno programeri su najtraženije zanimanje u IT kategoriji. Ovde Treba napomenuti da jedan 
oglas sadrži više stavki koje kandidat treba da poseduje

Sledi kratak prikaz rezultata istraživanja po pojedinačnim segmentima.

\subsection{Programski i skript jezici i tehnologije}

Od programskih jezika Java se javljala u 28,53\% (od ukupnog broja stavki vezano za poznavanje nekog programskog jezika), potom slede PHP
$(24,19 \%)$ i C\# $(23,13 \%)$ (Slika 3). Sa druge strane, izgleda da su Delfi programeri otišli u zaborav, jer se poznavanje Pascal programskog jezika kojim se oni bave pojavilo u svega 11 oglasa $(0,39 \%)$ tokom 2013. godine.

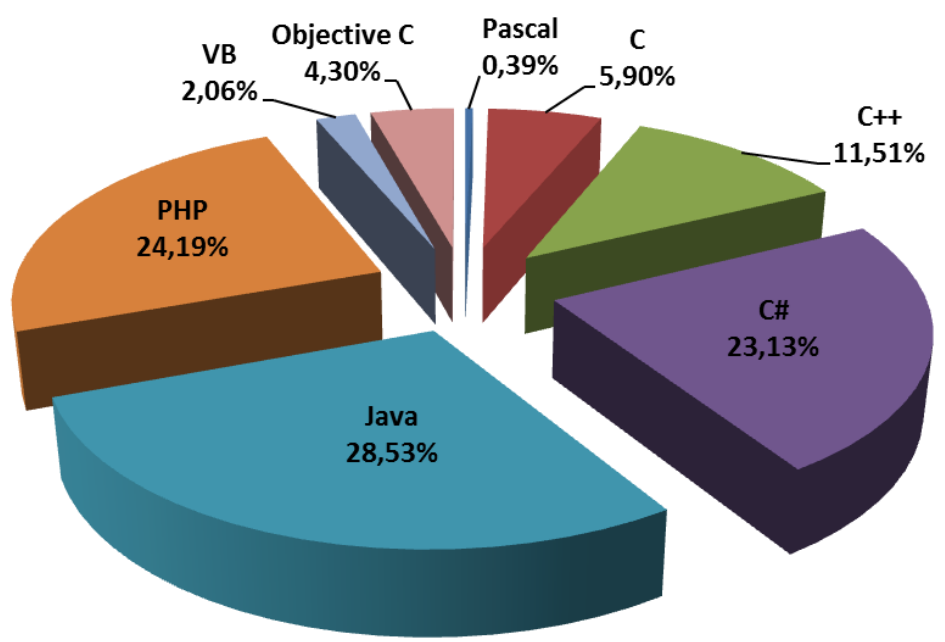

Slika 3. Potražnja za poznavanjem određenih programskih jezika

U skript jezicima najzastupljenija je potreba za poznavanjem HTML-a $i$ to $u$ svim njegovim varijetetima. Kao što se na slici 4 vidi HTML je "grupisan" zajedno sa XML, iz razloga što se u većini oglasa kad se navede HTML navodi i poznavanje XML-a. Ovo je i razumljivo jer XML u stvari i predstavlja jednu vrstu "naslednika" HTMLa. Sa slike 4 se takođe uočava da je znanje JavaScript-a i jQuery-ija poželjno. U stvari, u najvećem broju slučajeva navodi se sve to (HTML, XML, JavaScript, jQuery). Skript jezici koji nisu navedeni na slici su bili neznatno zastupljeni.

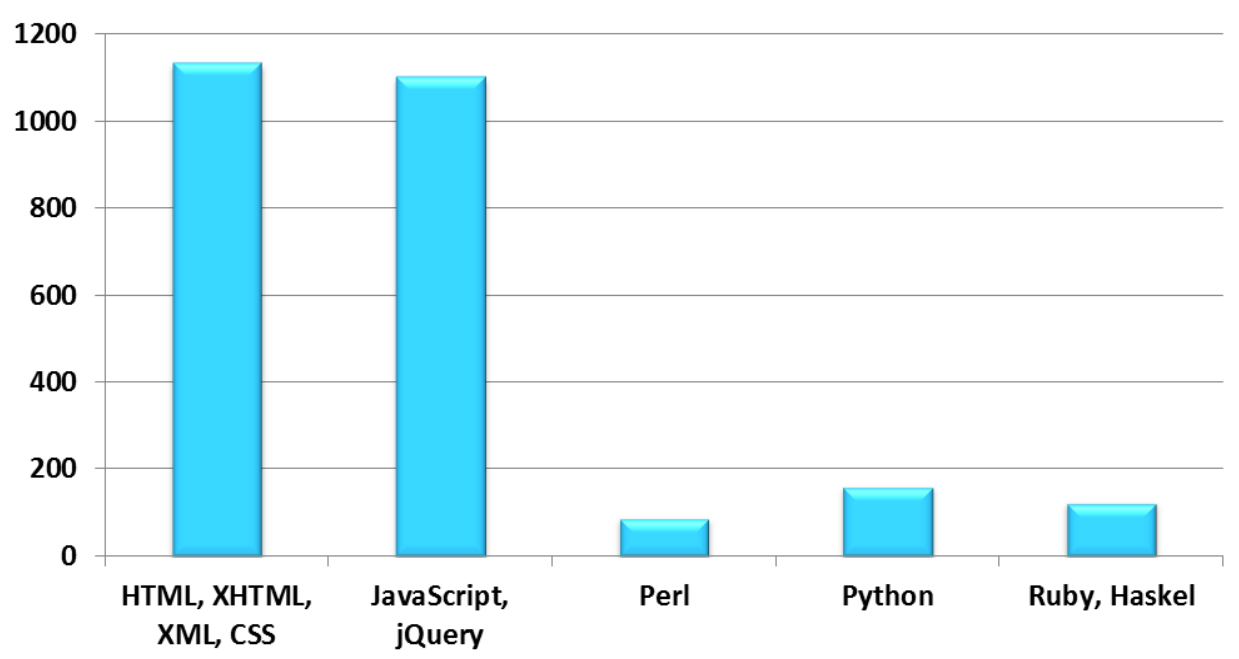

Slika 4. Potražnja za poznavanjem određenih skript jezika

Što se tiče poznavanja rada $u$ određenom prikazane samo one koje su bile najzastupljenije $u$ software framework-u (tehnologiji) na slici 5 su oglasima. Odnosno, na slici 5 je prikazano 
kretanje tražnje po mesecima tokom 2013. godine. Uočava se da je najčešće zahtevano znanje ASP.NET (ovde se misli na ASP.NET WebForms). Uz poznavanje ASP.NET MVC to je predstavljalo idealnu kombinaciji koju su poslodavci zahtevali.
Potražnja za mobilnim aplikacijama (Android, iOS) je evidentno povećana od avgusta meseca 2013. godine. Sve do novembra meseca programiranje za mobilnim aplikacije je imalo primat u odnosu na ostale platforme. Ovde nije navedeno razvijanje mobilnih aplikacija za Windows platformu, jer su se oni tražili u neznatnom broju oglasa.

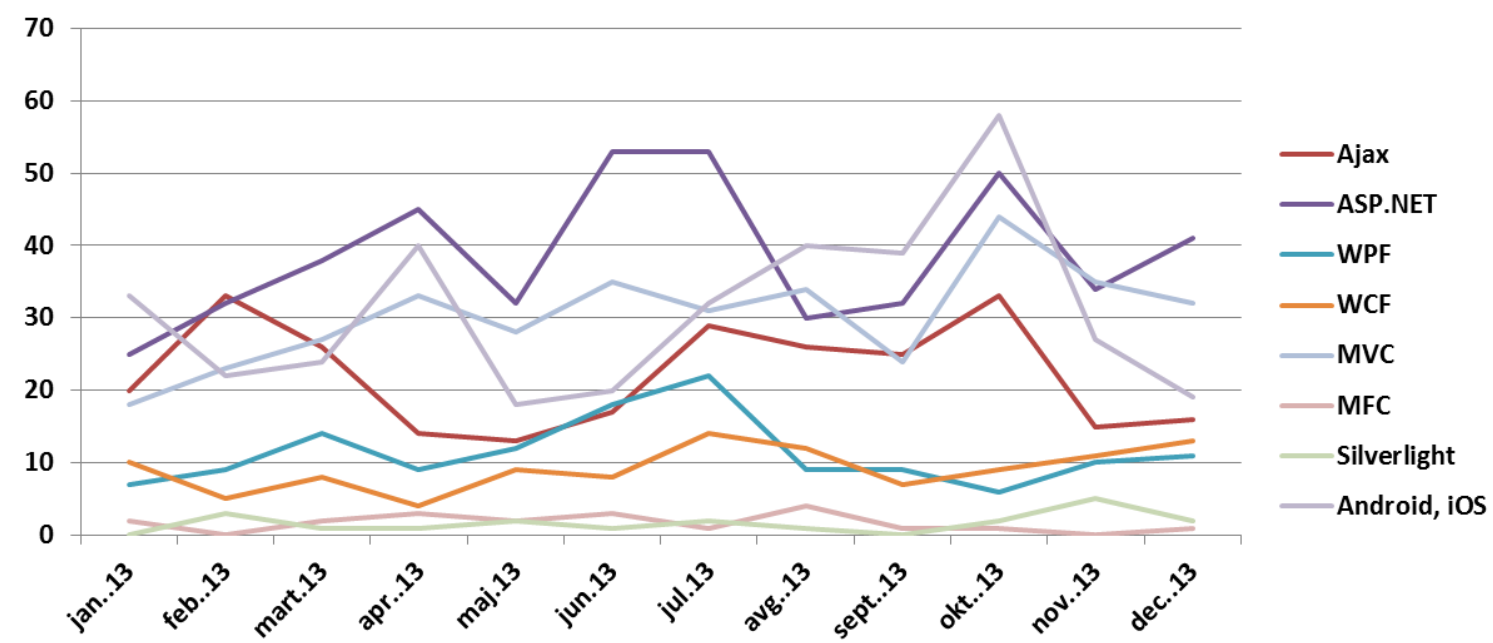

Slika 5. Potražnja za poznavanjem određenih software frameworks

\subsection{Baze podataka i operativni sistemi}

U oko 43\% slučajeva (kada se u oglasu specificiralo poznavanje rada u nekoj bazi podataka) traženo je znanje MSSQL, potom MySQL baze (oko 34\%) i Oracle (oko 14\%).

Za operativne sisteme se uglavnom u oglasima koji su se odnosili na administratore sistema, administratore mreža i drugih sličnih zanimanja, navodilo znanje kog OS je neophodno. Podrazumevalo se da se zna Microsoft operativni sistem u svim njegovim verzijama (bar ovim novijim). Pored toga traži se Linux $(93,80 \%)$ i Mac $(6,20 \%)$.

\subsection{Multimedijalne tehnologije}

Adobe alati su najzastupljeniji u oglasima u kojima se traži poznavanje neke multimedijalne tehnologije i alata. Sa slike 6 se vidi da se najviše traži poznavanje Photoshop-a (41\%), Illustrator-a (24\%) i Flash-a (17\%). Multimedijalni alati koji nisu navedeni na slici su bili neznatno zastupljeni.

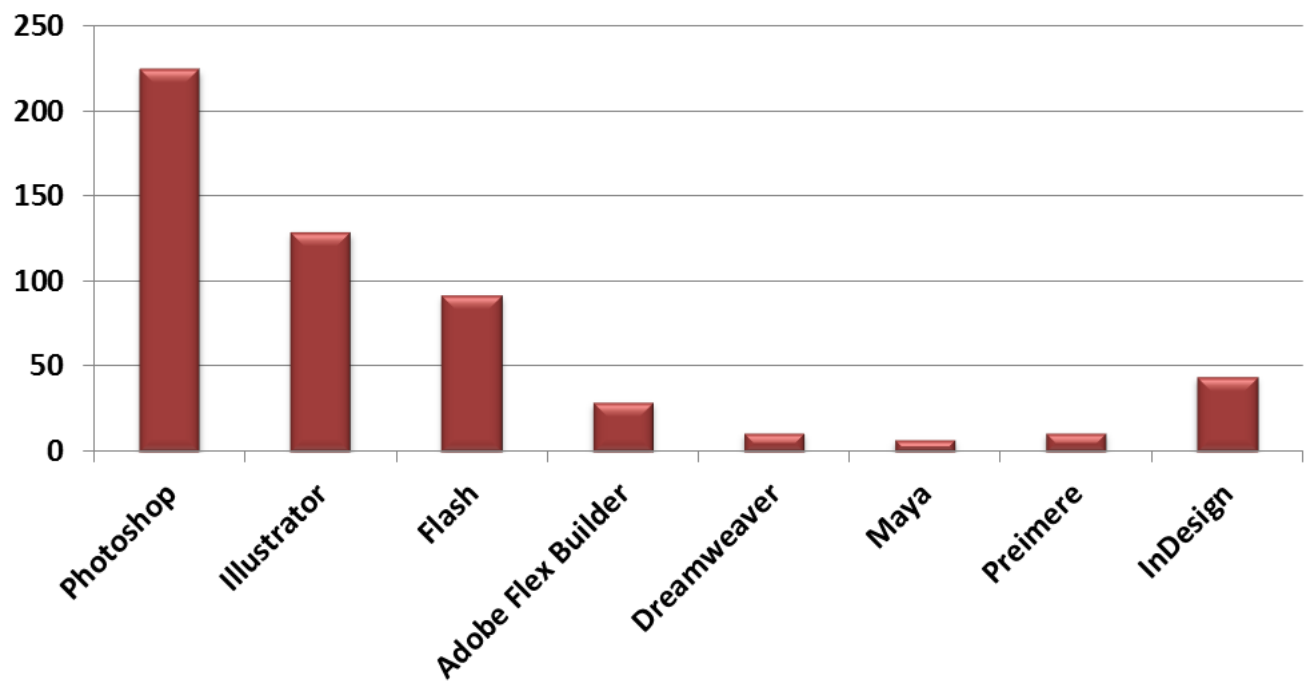

Slika 6. Potražnja za poznavanjem određenih multimedijalnih tehnologija 


\section{OBRAZOVANJE IT KADROVA}

\subsection{IT profili koji se traže}

Prema godišnjem istraživanje koje sprovodi Computerworld.com, top IT veštine za 2014. godinu će biti: programeri (49\%), tehnička podrška $(37 \%)$, administracija mreže (31\%), razvoj mobilnih aplikacija (27\%), menadžment projekata u IT $(25 \%)$, administracija baza podataka (24\%), bezbednost informacionih sistema (21\%), analiza i poslovno izveštavanje (18\%) (Brandel, 2013).

$\mathrm{Na}$ osnovu navedenih podataka iz istraživanja koje je sprovela Visoka škola strukovnih studija ITS, a koji se u velikoj meri poklapaju sa podacima u svetu, zaključuje se da treba školovati programere i to prvenstveno programere za razvoj veb i mobilnih aplikacija.

Da se traže veb programeri se zaključuje se na osnovu velike tražnje Java i PHP jezika, skript jezika, potom ASP.NET WebForms (podrazumeva se i C\# programski jezik) i MVC tehnologija. $\mathrm{Na}$ početku rada je rečeno i da sve firmi u Srbiji koristi računare u svom poslovanju, skoro sve koriste i internet, a preko $3 / 4$ njih ima i svoj veb sajt, pa je logična i potražnja za veb programerima.

Najveća poslovna društvena mreža Linkedln sprovela je istraživanje koje je uključilo 259 miliona profila koji se nalaze na ovoj mreži kako bi utvrdili koji su to poslovi koji nisu postojali 2008. godine. Na prvom mestu našli su se iOS i Android diveloperi, tj. programeri za mobilne aplikacije. Za samo 5 godina, broj Android programera na ovoj mreži povećao se skoro 200 puta, sa svega pedesetak 2008. godine, do preko 10.000 koliko ih je bilo 2013. godine (10 popularnih zanimanja koja jedva da su postojala pre 5 godina, 2014). Ovo se poklapa sa analizom koju je uradio ITS, a koja je pokazala da se od avgusta meseca potražnja za programerima mobilnih aplikacija znatno povećala i na tržištu rada u Srbiji.

Ovakva situacija uopšte ne čudi, ako se uzme u obzir da prema podacima Republičkog zavoda za statistiku u Srbiji čak $86,9 \%$ stanovništva ima mobilni telefon, najviše populacija od 16 do 24 godine. Takođe, impozantan je podatak da čak 93,4\% navedene internet populacije (od 16 do 24 godina starosti) ima nalog na društvenim mrežama (Facebook, Twitter) (Upotreba informaciono-komunikacionih tehnologija u
Republici Srbiji, 2013). Ovi podaci bi trebalo jasno da ukažu i IT menadžerima koje aplikacije treba kreirati i ponuditi na tržištu.

\subsection{Formalno obrazovanje}

Svi smo svesni činjenice da se sistem obrazovanja nije adekvatno menjao i prilagođavao novonastalim potrebama. Sprovođenje Bolonjske deklaracije se uglavnom svodi na formalno ispunjavane propisanih standarda na većini visokoobrazovnih ustanova kod nas. Takođe, eventualna fleksibilnost nastavnog procesa je svedena na minimum zbog tromog sistema dobijanja dozvola od strane Akreditacione komisije, a za svaku izmenu strukture studijskog programa ili izmenu nastavnog plana i programa mora se dobiti saglasnost iste.

Visokoškolskim ustanovama jedino preostaje da uvode izmene $u$ nastavne predmete $u$ onom obimu za koji se ne zahteva obavezna saglasnost Akreditacione komisije.

Naš obrazovni sistem se previše bazira na teoriji, a ne na praksi. Studenti nakon uspešno završenih studija, nažalost, poseduju malo funkcionalnog, primenjivog znanja. Osnovi razlog za to je što $u$ toku svog školovanja nisu ni upućivani na ovaj način razmišljanja i sticanja znanja. Neophodno je izmeniti čitav nastavni proces, od nastavnih materijala i načina izlaganja nastavne materije, pa do samog sistema ispitivanja i procene studentovog znanja.

$\mathrm{Na}$ Visokoj školi strukovnih studija ITS je kao obavezujući segment uvedena problemski orijentisana nastava i polaganje ispita, kao i interaktivna nastava u različitim modalitetima što zavisi od prirode i strukture samog predmeta. Nema više samo suvoparne teorije i frontalnog slušanja predavanja. Studenti su aktivni u toku nastave i uključeni su u manjem ili većem obimu na časovima.

Kako bi svršeni student ITS-a bili konkurentni na tržištu čim završe studije, a čak i pre toga (tokom studija), na Školi se sprovode određeni vidovi obavezne i neobavezne prakse. Praksa je usklađena sa trendovima na tržištu. Tako je tokom prošle i ove godine organizovano više praksi za razvoj Android mobilnih aplikacija. Studenti koji su više orijentisani na računarsku multimediju mogili su da se uključe u praksu sa temom "Front end 
koncepti za web i mobilne aplikacije", koja je podrazumevala praktičan rad sa inženjerima jedne softverske kuće. Takođe, u okviru samih predmeta zadaju im se obavezani projekti koje razvijaju od početka do kraja (od projektovanja do implementacije). Odnosno, insistira se na radu na realnim projektima koji će in čekati u profesionalnom životu, što između ostalog podrazumeva i timski rad.

Ovakav pristupa nastavnom procesu ITS-a daje odlične rezultate. Naime, prema podacima iz januara 2014. godine čak $84,26 \%$ studenata koji su uspešno završili ovu Školu je zaposleno u struci, a $8,31 \%$ je nastavilo svoje školovanje u Srbiji i inostranstvu.

Takođe, problem je što obrazovni sistem, odnosno nacionalni okvir kvalifikacija u Srbiji ne prepoznaje neka zanimanja, uvedena pre par godina, a za kojima postoji značajna potražnja. Ovo se svakako mora promeniti u što skorije vreme. Nacionalni savet za visoko obrazovanje, koji je definisan Zakonom o visokom obrazovanju, je usvojio tekst nacionalnog okvira kvalifikacija Srbije još aprila meseca 2010. godine i od tada se čeka njegovo usvajanje.

Evidentan je i problem ne usklađenih upisnih kvota na visokoobrazovnim ustanovama realnom stanju na tržištu. Tom problematikom se ovaj rad neće baviti.

\subsection{Neformalno obrazovanje}

Zbog nedostatka posla u struci mnogi ljudi se odlučuju na različite vidove prekvalifikacija, odnosno dokvalifikacija iz određene oblasti. Za to najčešće biraju neke vidove neformalnog obrazovanja, kao što su kursevi, seminari, obuke i slično.

S obzirom da firme koje se bave ovakvim vidom obrazovanja nemaju striktna pravila zadata od strane nekog državnog organa, u smislu nastavnog procesa (plan i program, način izvođenja nastave i polaganja ispita), u Srbiji postoji znatan broj njih. Ono po čemu se one razlikuju to je kvalitet, trajanje obuke, obim, ...

Kako se često govori da su IT stručnjaci traženi, a i dobro plaćeni, veliki broj osoba se odlučuje baš za ovu oblast. Kursevi koji su u kod nas u ponudi su iz različitih užih oblasti specijalizacije. $\mathrm{Na}$ primer na IT Akademiji tokom jedne godine polaznici prolaze usko specijalizovane obuke za programere, web dizajnere, stručnjake za razvoj kompjuterskih mreža, odnosno zanimanja koja su veoma tražena na tržištu rada. Tako je i sve veći broj onih koji su zainteresovani za programiranje mobilnih aplikacija.

\section{ZAKLJUČAK}

Tržišni trendovi se moraju pratiti u svim svojim domenima i shodno njima moraju se prilagođavati odgovarajuće društvene karike svake zemlje. Analogno tome i obrazovni sistem jedne zemlje se mora permanentno prilagođavati tim trendovima. Velika nezaposlenost u Srbiji se donekle može umanjiti $\mathrm{i}$ školovanjem konkurentnih kadrova $\mathrm{u}$ zanimanjima koja su deficitarna na tržištu.

IT sektor je svakako najzastupljeniji u svim domenima poslovanja, pa stoga i velika potražnja za IT stručnjacima. U Srbiji se najviše traže programeri veb i mobilnih aplikacija, potom administrator baza podataka i mreža, dizajneri, ... Neophodno je što pre prilagoditi obrazovni sistem (formalno i neformalno obrazovanje) kako bi se dobio kompetentan i kvalitetan kadar. Moraju se menjati mnogi zakonski okviri, ali ima i prostora na kome svaka visokoškolska ustanova može i mora da usavrši i dodatno poboljša u svom radu.

Jedno od rešenja je dodatno revidirati nastavne planove i programe. Uskladiti in sa kompetencijama koje poslodavci zahtevaju od svojih kadrova. Insistirati na praktičnom znanju, pa shodno tome prilagoditi i način izvođenja nastave. Neke od metoda koje su dale dobre rezultate su problemski orijentisana nastava i polaganje ispita, kao i interaktivna nastava kroz razne radionice, simulacije, timski rad, konstruktivne debate, ...

\section{CITIRANI RADOVI}

10 popularnih zanimanja koja jedva da su postojala pre 5 godina. (2014, januar). Preuzeto januar 25, 2014 sa LINKGroup: http://www.link.co.rs/media-room/10-popularnih-zanimanja-koja-jedva-dasu-postojala-pre-5-godina 
Aktuelni pokazatelji - Anketa o radnoj snazi. (2013, oktobar). Preuzeto mart 20, 2014 sa Republički zavod za statistiku, Republika Srbija: http://webrzs.stat.gov.rs/WebSite/Public/PageView.aspx?pKey=2

Brandel, M. (2013, septembar 23). 8 hot IT skills for 2014. Preuzeto mart 20, 2014 sa Computerworld: http://www.computerworld.com/s/article/9242548/8_hot_IT_skills_for_2014

Mesečni statistički bilten za februar 2014. godine. (2014, mart). Preuzeto mart 20, 2014 sa Nacionalna služba za zapošljavanje $\quad$ Republike Srbije: http://www.nsz.gov.rs/live/digitalAssets/1/1796_bilten_nsz_02_2014.pdf

MOR, M. o. (2015, Jan 21). MOR: Blagi pad nezaposlenosti u Srbiji. Retrieved from RTS Radio-televizija Srbije:

http://www.rts.rs/page/stories/sr/story/13/Ekonomija/1805807/MOR\%3A+Blagi+pad+nezaposl enosti+u+Srbiji.html

Srbiji potrebni IT stručnjaci. (2014, mart 03). Preuzeto mart 25, 2014 sa Međunarodni radio Srbija: http://www.glassrbije.org/\%C4\%8Dlanak/srbiji-potrebni-it-stru\%C4\%8Dnjaci

Upotreba informaciono-komunikacionih tehnologija u Republici Srbiji. (2013, septembar 23). Preuzeto januar 24, 2014 sa Republički zavod za Statistiku Republike Srbije: http://webrzs.stat.gov.rs/WebSite/repository/documents/00/01/14/03/PressICT2013.pdf

Datum prve prijave:

28.02.2014.

Datum prijema korigovanog članka:

Datum prihvatanja članka:
30.03.2014.

23.03.2015.

\section{Kako citirati ovaj rad? / How to cite this article?}

Style - APA Sixth Edition:

Anđelić, S., \& Kuleto, V. (2015, jul 15). Savremene tendencije u obrazovanju IT stručnjaka. (Z. Čekerevac, Ed.) FBIM Transactions, 3(2), 1-8. doi:10.12709/fbim.03.03.02.01

Style - Chicago Sixteenth Edition:

Anđelić, Svetlana, and Valentin Kuleto. 2015. "Savremene tendencije u obrazovanju IT stručnjaka." Edited by Zoran Čekerevac. FBIM Transactions (MESTE) 3 (2): 1-8. doi:10.12709/fbim.03.03.02.01.

Style - GOST Name Sort:

Anđelić Svetlana and Kuleto Valentin Savremene tendencije u obrazovanju IT stručnjaka [Journal] // FBIM Transactions / ed. Čekerevac Zoran. - Beograd : MESTE, jul 15, 2015. - 2 : Vol. 3. - pp. 1-8.

Style - Harvard Anglia:

Anđelić, S. \& Kuleto, V., 2015. Savremene tendencije u obrazovanju IT stručnjaka. FBIM Transactions, 15 jul, 3(2), pp. 1-8.

Style - ISO 690 Numerical Reference:

Savremene tendencije u obrazovanju IT stručnjaka. Anđelić, Svetlana and Kuleto, Valentin. [ed.] Zoran Čekerevac. 2, Beograd : MESTE, jul 15, 2015, FBIM Transactions, Vol. 3, pp. 1-8. 